\title{
A Brief Survey of Preparation and Heat Transfer Enhancement of Hybrid Nanofluids
}

\author{
Ahmed A. Hussien ${ }^{1}$ - Wael Al-Kouz ${ }^{2} *$ - Nadiahnor Md Yusop ${ }^{3}$ - Mohd Z. Abdullah ${ }^{4}$ - Ayub Ahmed Janvekar ${ }^{4}$ \\ ${ }^{1}$ Al-Hussein Bin Talal University, Department of Mechanical Engineering, Jordan \\ ${ }^{2}$ German Jordanian University, Mechatronics Engineering Department, Jordan \\ 3 Universiti Teknologi MARA Faculty of Chemical Engineering, Malaysia \\ ${ }_{4}^{4}$ Universiti Sains Malaysia, School of Mechanical Engineering, Malaysia
}

The investigation of the domestic application of heat flux dissemination is in high demand. The best strategy to obtain a coolant with an ideal execution is by including particular sorts of nanoparticles in the base fluid. The utilization of nanofluids escalates the heat transfer coefficient through the enhancement of the base fluid's thermal conductivity. An advanced coolant (hybrid nanofluid) was delivered by blending two or more different types of nano-sized particles with conventional fluid. This article mainly aims to cover the recent publications on hybrid nanofluids on different aspects, such as preparation, thermophysical properties, and heat transfer enhancement. In general, the combination of different nanoparticle properties results in excellent thermal conductivity: improvement in heat transfer coefficient was up to $148 \%$ compared to the base fluid. Moreover, a moderate increase on pressure drop has been detected due to the presence of composite nanoparticles. In any case, the anticipated results for both thermal conductivity and viscosity values utilizing conventional relationships were distinctive from the experimental results.

Keywords: hybrid nanofluids, Nusselt number, thermal conductivity, viscosity, thermal applications

Highlights

- Hybrid nanofluids are produced by mixing two or more nanoparticles types with a base fluid, via physical or chemical processes.

- Using hybrid nanofluids provides an enormous enhancement in thermophysical and rheological properties.

- A significant enhancement in the heat transfer coefficient for hybrid nanofluid compared to water base fluid is presented.

- $\quad$ The effect of hybrid nanofluids in reducing the pressure drop is observed.

\section{INTRODUCTION}

High heat flux dissipation is one of the most prominent reasons that has motivated many researchers to put their best efforts into producing new cooling systems (or new coolants).

In 1995, Choi presented the term "nanofluid" as an expression for base fluid that contains very small particles $(<100 \mathrm{~nm})$ called "nanoparticles" [1]. This advanced method was introduced mainly to prevent overheating in many common applications, such as electronic cooling, solar cells, and automotive cooling systems. However, issues such as clogging, erosion, nanoparticles sedimentation, and high cost are the main challenges in extending nanofluid within the industrial sector [2]. For example, metallic nanoparticles have high thermal conductivity and good electrical properties, but they produce low stability and chemically inert fluid. In contrast, metals oxide nanoparticles have low thermal conductivity with high stability in the fluid. The combination of these two nanoparticles types provides the preferred characteristics for a favourable coolant. Therefore, many researchers aspired to mix two or more nanoparticles types with a base fluid to produce hybrid nanofluids, via physical or chemical processes. Hybrid nanofluids may have higher thermal conductivity that can further improve heat transfer and pressure drop properties [3].

Recently, there has been a sharply increased demand for research in hybrid nanofluids that enhance thermophysical and heat transfer properties. Thus, attempts have been made to prepare an article that may come in handy in fulfilling those demands. Many research studies focused only on the thermophysical properties of hybrid nanofluids, and some focused on its application mainly in enhancing the heat transfer coefficient. However, this article considers a systematic approach, focusing on recently published articles related to hybrid nanofluids, specifically in hybrid nanofluid preparation, thermophysical properties, and heat transfer coefficient enhancement.

\section{PREPARATION OF HYBRID NANOFLUIDS}

There are many methods for nanomaterial synthesis, such as chemical vapour deposition (CVD), vacuum deposition and vaporisation, and sol-gel techniques 
[4] and [5]. There are two methods used in preparing hybrid nanofluids, known as one-step and two-step methods. Most scholars utilise the two-step method in preparing hybrid nanofluids, but some synthesize the nanocomposite $(\mathrm{NC})$ particles before they are dispersed in base fluids. The NC particles could be synthesized through several methods such as a pure chemical reaction [6], a thermochemical method [7], and an in-situ method [8].

Yarmand et al. [9] presented a new synthesis method in preparing graphene nanoplatelets (GNP)$\mathrm{Ag} /$ water hybrid nanofluid, which produces silver on functionalized GNP through a simple chemical reaction process.

Megatif et al. [10] prepared $\mathrm{TiO}_{2}-$ carbon nanotube (CNT) nanocomposite by using hydrolysis technique. They obtained a CNT dispersion by mixing the CNTs with $\mathrm{HNO}_{3}-\mathrm{H}_{2} \mathrm{SO}_{4}$, followed by ethylene glycol (EG) and $20 \mathrm{ml}$ of 2-propanol. Subsequently, $\mathrm{Ti}(\mathrm{OBu})_{4}$ was added into the suspension for special treatment. The nanocomposite was obtained after vacuum filtering, washing in 2-propanol, and drying of $\mathrm{CNT}-\mathrm{TiO}_{2}$. Suresh et al. [7] synthesized $\mathrm{Al}_{2} \mathrm{O}_{3}-\mathrm{Cu}$ nanocomposite particles by using the thermochemical method as described in Fig.1. Hybrid nanofluids were prepared by dispersing the nanocomposite particles in the deionized water together with sodium lauryl sulphate (SLS). The stability of the prepared powder was then observed in different volume concentrations of hybrid nanofluid. Some researchers prepare hybrid nanofluids by mixing two nanoparticles types, which separately synthesized within the base fluid. Harandi et al. [11] employed the two-step method in preparing f- multiwall carbon nanotubes (MWCNTs) $-\mathrm{Fe}_{3} \mathrm{O}_{4} /$ EG hybrid nanofluid. Dry f-MWCNTs and $\mathrm{Fe}_{3} \mathrm{O}_{4}$ nanoparticles were mixed in ethylene glycol and were prepared in different volume fractions. Ultrasonic vibration instrument was used to obtain good stability, as shown in Fig. 2. Akilu et al. [12] utilized the wetmixing method to synthesize titanium oxide-copper oxide/carbon $\left(\mathrm{TiO}_{2}-\mathrm{CuO} / \mathrm{C}\right)$-based nanocomposites. After that, they prepared stable EG based hybrid nanofluids through the two-step method to develop the thermophysical properties of the base fluid. Sundar et al. [13] synthesized nanodiamond-nickel (ND-Ni) nanocomposite materials through the in-situ growth and chemical co-precipitation method.

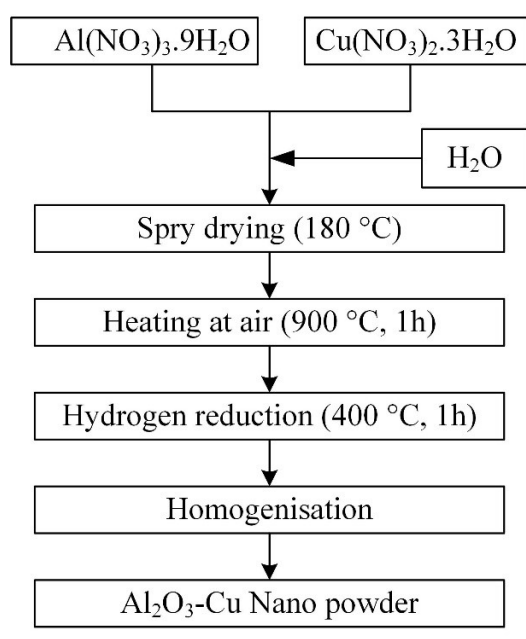

Fig. 1. Schematic diagram of Al203-Cu synthesis through the thermochemical procedure

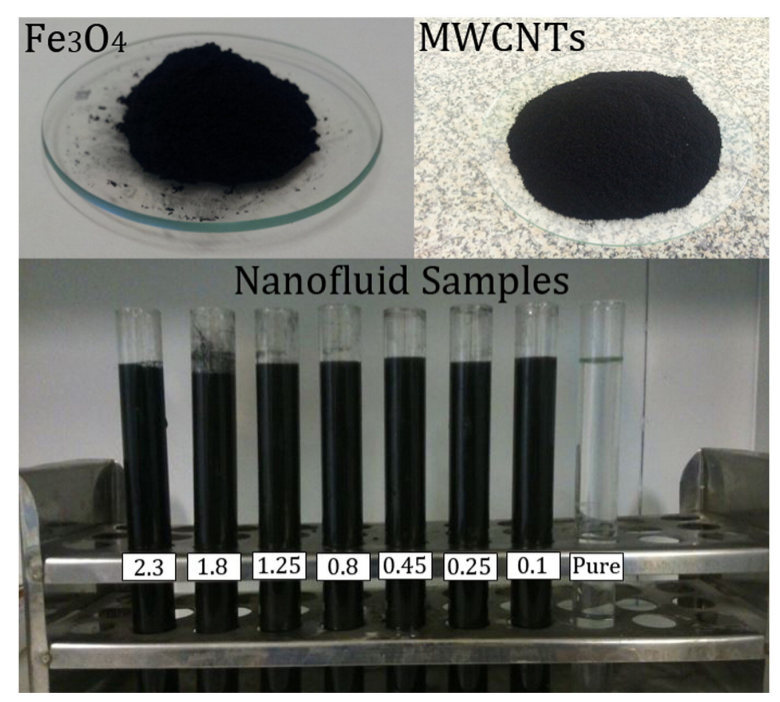

Fig. 2. f-MWCNTS-Fe304/EG hybrid nanofluid with different volume concentration [11]

Table 1 shows that researchers preferred to combine metallic or metallic oxide with carbon nanoparticles families (CNTs, MWCNTs, GNPs, and diamonds) because of their high thermal conductivities, low densities, and better performance in electric behaviour. Table 1 describes the recent works done in hybrid nanofluids. In this table, the majority used one or more of these methods (adding surfactants, using ultrasonic vibration, fictionalizations agent, and controlling $\mathrm{pH}$ value methods) to stabilize the hybrid nanofluids. The main intention was to prepare hybrid nanofluids in order to study the thermophysical and rheological properties and the convective heat transfer enhancement in selected applications. 
Table 1. The preparation methods of hybrid nanofluids

\begin{tabular}{|c|c|c|c|c|c|}
\hline Reference & $\begin{array}{l}\text { Hybrid } \\
\text { nanoparticle }\end{array}$ & $\begin{array}{l}\text { Dispersant } \\
\text { fluid }\end{array}$ & vol.\% / wt.\% & Stability methods & Main objective \\
\hline Han et al. [14] & $\begin{array}{l}\mathrm{NC}) \\
\mathrm{Al}_{2} \mathrm{O}_{3}+\mathrm{Fe}_{2} \mathrm{O}_{3}+\mathrm{CNT}\end{array}$ & $\begin{array}{l}\text { poly-alpha- } \\
\text { olefin (PA0) }\end{array}$ & $0.1,0.2$ vol. $\%$ & $\begin{array}{l}\text { Sonication and surfactant } \\
\text { (Span-80) }\end{array}$ & $\begin{array}{l}\text { studying the effective thermal } \\
\text { conductivity }\end{array}$ \\
\hline Chen et al. [15] & (NC)Ag/MWNT & water & 1.0 vol. $\%$ & $\begin{array}{l}\text { Sodium dodecyl sulphate } \\
\text { (SDS) }\end{array}$ & $\begin{array}{l}\text { studying the effective thermal } \\
\text { conductivity }\end{array}$ \\
\hline $\begin{array}{l}\text { Suresh et al. } \\
{[16]}\end{array}$ & (NC) $\mathrm{Al}_{2} \mathrm{O}_{3}-\mathrm{Cu}$ & water & 0.1 vol. $\%$ & $\begin{array}{l}\text { ultrasonic vibrator, and } \\
\text { sodium lauryl sulphate (SLS) }\end{array}$ & $\begin{array}{l}\text { enhancing convective heat transfer } \\
\text { and pressure drop }\end{array}$ \\
\hline $\begin{array}{l}\text { Khosravifard et } \\
\text { al. [17] }\end{array}$ & $\mathrm{TiO}_{2}$-CNTs & $\begin{array}{l}\text { propylene } \\
\text { glycol + } \\
\text { water }\end{array}$ & & $\begin{array}{l}\text { ultrasonic agitator, and } \\
\text { (SDS) }\end{array}$ & $\begin{array}{l}\text { studying the characterization and } \\
\text { thermophysical properties }\end{array}$ \\
\hline $\begin{array}{l}\text { Selvakumar and } \\
\text { Suresh [18] }\end{array}$ & $(\mathrm{NC}) \mathrm{Al}_{2} \mathrm{O}_{3}-\mathrm{Cu}$ & water & 0.1 vol. $\%$ & ultrasonic vibrator, and (SLS) & enhancing convective heat transfer \\
\hline Safi et al. [19] & (NC)MWCNT-TiO 2 & water & 0.02 wt. $\%$ to 0.08 wt. $\%$ & ultrasonic agitator & enhancing convective heat transfer \\
\hline Nine et al. [20] & $\mathrm{Al}_{2} \mathrm{O}_{3}$-MWCNTs & water & 1 wt. $\%$ to 4 wt. $\%$ & ultrasonic vibrator & $\begin{array}{l}\text { studying the characterization and } \\
\text { thermophysical properties }\end{array}$ \\
\hline $\begin{array}{l}\text { Sundar et al. } \\
{[21]}\end{array}$ & (NC)Diamond+Ni & $\begin{array}{l}\text { water and } \\
\mathrm{EG}\end{array}$ & 0.1 vol. $\%$ to 0.3 vol. $\%$ & $\begin{array}{l}\text { ultrasonic vibrator, and } \\
\text { NanoSperse } A Q\end{array}$ & $\begin{array}{l}\text { enhancing convective heat transfer } \\
\text { and pressure drop }\end{array}$ \\
\hline $\begin{array}{l}\text { Madhesh et al. } \\
\text { [22] }\end{array}$ & $(\mathrm{NC}) \mathrm{Cu}-\mathrm{TiO}_{2}$ & water & 0.1 vol. $\%$ to 2 vol. $\%$ & $\begin{array}{l}\text { ultrasonic vibrator without } \\
\text { surfactant }\end{array}$ & enhancing convective heat transfer \\
\hline Esfe et al. [23] & $\mathrm{Ag}-\mathrm{MgO}$ & water & 0 vol. $\%$ to 2.0 vol. $\%$ & $\begin{array}{l}\text { ultrasonic vibrator and } \\
\text { CetylTrimethyl Ammonium } \\
\text { Bromide (CTAB) }\end{array}$ & $\begin{array}{l}\text { studying the effective thermal } \\
\text { conductivity }\end{array}$ \\
\hline Esfe et al. [24] & CNTs- $\mathrm{Al}_{2} \mathrm{O}_{3}$ & water & 0.02 vol. $\%$ to 1 vol. $\%$ & ultrasonic vibrator & $\begin{array}{l}\text { studying the effective thermal } \\
\text { conductivity }\end{array}$ \\
\hline $\begin{array}{l}\text { Yarmand et } \\
\text { al. [9] }\end{array}$ & (NC)GNP-Ag & water & 0 vol. $\%$ to 0.1 vol. $\%$ & ultrasonic vibrator & $\begin{array}{l}\text { enhancing convective heat transfer } \\
\text { and pressure drop }\end{array}$ \\
\hline $\begin{array}{l}\text { Baghbanzadeh } \\
\text { et al. [25] }\end{array}$ & silica + MWCNTs & water & 1.0 wt. $\%$ & SDBS & studying the rheological properties. \\
\hline $\begin{array}{l}\text { Sundar et al. } \\
{[26]}\end{array}$ & (NC)CNT- $\mathrm{Fe}_{3} \mathrm{O}_{4}$ & water & 0.1 vol. $\%$ to 0.3 vol. $\%$ & $\begin{array}{l}\text { (situ method) and } \\
\text { NanoSperse } A Q\end{array}$ & $\begin{array}{l}\text { enhancing convective heat transfer } \\
\text { and pressure drop }\end{array}$ \\
\hline $\begin{array}{l}\text { Madhesh et al. } \\
\text { [27] }\end{array}$ & $\mathrm{Ag}+\mathrm{CuO}$ & water & 1 vol. $\%$ & ultrasonic vibrator & $\begin{array}{l}\text { enhancing convective heat transfer } \\
\text { and pressure drop }\end{array}$ \\
\hline $\begin{array}{l}\text { Eshgarf and } \\
\text { Afrand [28] }\end{array}$ & MWCNTS-SiO 2 & $\mathrm{EG}$, water & 0.0625 vol. $\%$ to 2 vol. $\%$ & $\begin{array}{l}\text { carboxyl (COOH) } \\
\text {-functionalized }\end{array}$ & studying the rheological properties. \\
\hline $\begin{array}{l}\text { Harandi et al. } \\
\text { [11] }\end{array}$ & F-MWCNTs- $\mathrm{Fe}_{3} \mathrm{O}_{4}$ & $E G$ & 0 vol. \% to 2.3 vol. $\%$ & ultrasonic vibrator & $\begin{array}{l}\text { studying the effective thermal } \\
\text { conductivity }\end{array}$ \\
\hline $\begin{array}{l}\text { Ramachandran } \\
\text { [29] }\end{array}$ & $\mathrm{Al}_{2} \mathrm{O}_{3}+\mathrm{CuO}$ & water & 0.1 vol. $\%$ & ultrasonic vibrator & enhancing convective heat transfer \\
\hline $\begin{array}{l}\text { Asadi and Asadi } \\
\text { [30] }\end{array}$ & $\mathrm{MWCNT}+\mathrm{ZnO}$ & engine oil & 0.125 vol. $\%$ to 1 vol. $\%$ & ultrasonic vibrator & studying the rheological properties \\
\hline Huang et al. [31] & $\mathrm{MWCNT}+\mathrm{Al}_{2} \mathrm{O}_{3}$ & water & $\begin{array}{l}\text { MWCNT } 0.0111 \text { vol. } \% \\
\mathrm{Al}_{2} \mathrm{O}_{3} 1.89 \text { vol. } \%\end{array}$ & ultrasonic vibrator & $\begin{array}{l}\text { enhancing convective heat transfer } \\
\text { and pressure drop }\end{array}$ \\
\hline Esfe et al. [32] & MWCNTS-SiO 2 & engine oil & 0 vol. $\%$ to 2 vol. $\%$ & ultrasonic vibrator & studying the rheological properties \\
\hline $\begin{array}{l}\text { Afrand et al. } \\
\text { [33] }\end{array}$ & $\mathrm{Fe}_{3} \mathrm{O}_{4}-\mathrm{Ag}$ & $\mathrm{EG}$ & 0.6 vol. $\%$ to1. 2 vol. $\%$ & ultrasonic vibrator & studying the rheological properties \\
\hline $\begin{array}{l}\text { Afrand et al. } \\
\text { [34] }\end{array}$ & $\mathrm{SiO}_{2}$-MWCNTs & engine oil & $0.625 \mathrm{vol} . \%$ to 1 vol. $\%$ & ultrasonic vibrator & studying the rheological properties \\
\hline $\begin{array}{l}\text { Allahyar et al. } \\
\text { [35] }\end{array}$ & $(\mathrm{NC}) \mathrm{Al}_{2} \mathrm{O}_{3}-\mathrm{Ag}$ & water & 0.1 vol. \% to 0.4 vol\% & sol-gel method & $\begin{array}{l}\text { studying the effective thermal } \\
\text { conductivity }\end{array}$ \\
\hline $\begin{array}{l}\text { Megatif et al. } \\
\text { [10] }\end{array}$ & $(\mathrm{NC}) \mathrm{TiO}_{2}-\mathrm{CNT}$ & Water & 0.1 vol. \% to 0.2 vol. $\%$ & $\begin{array}{l}\text { hydroxyl }(-\mathrm{OH}) \text { and carboxyl } \\
(-\mathrm{COOH}) \text { functionalized }\end{array}$ & enhancing convective heat transfer \\
\hline $\begin{array}{l}\text { Toghraie et al. } \\
\text { [36] }\end{array}$ & $\mathrm{ZnO}-\mathrm{TiO}_{2}$ & $E G$ & 0 vol. \% to 3.5 vol. $\%$ & ultrasonic vibrator & $\begin{array}{l}\text { studying the effective thermal } \\
\text { conductivity }\end{array}$ \\
\hline
\end{tabular}


Table 2. The proposed correlations for thermophysical properties of hybrid nanofluids

\begin{tabular}{|c|c|c|}
\hline Reference & Hybrid nanofluids type & The proposed correlations \\
\hline Sunder et al. [21] & Diamond+Ni / water, EG & $\frac{k_{n f}}{k_{b f}}=1+4.01 \varnothing, \quad \frac{\mu_{n f}}{\mu_{b f}}=1.35 e^{12.83 \varnothing}$ \\
\hline Esfe et al. [23] & $\mathrm{Ag}-\mathrm{MgO} /$ water & $\begin{aligned} \frac{k_{n f}}{k_{b f}} & =\frac{0.1747 \times 10^{5}+\varnothing}{0.1747 \times 10^{5}-0.1498 \times 10^{6} \varnothing+0.1117 \times 10^{7} \varnothing^{2}+0.1997 \times 10^{8} \varnothing^{3}}, \\
\frac{\mu_{n f}}{\mu_{b f}} & =1+32.795 \varnothing-7214 \varnothing^{2}+714600 \varnothing^{3}-0.1941 \times 10^{8} \varnothing^{4}\end{aligned}$ \\
\hline Harandi et al. [11] & F-MWCNTs-Fe304/EG & $\frac{k_{n f}}{k_{b f}}=1+0.0162 \varnothing^{0.7038} T^{0.6009}$ \\
\hline Asadi and Asadi [30] & MWCNT + ZnO / engine oil & $\mu_{n f}=796.8+76.26 \varnothing+12.88 T+0.7695 \varnothing T+\frac{-196.9 T-16.53 \varnothing T}{\sqrt{T}}$ \\
\hline Afrand et al. [34] & $\mathrm{SiO}_{2}-\mathrm{MWCNTs}$ / engine oil & $\frac{\mu_{n f}}{\mu_{b f}}=a_{0}+a_{1} \varnothing+a_{2} \varnothing^{2}+a_{3} \varnothing^{3}+a_{4} \varnothing^{4}$, , where 's are factors depend on T \\
\hline Toghraie et al. [36] & $\mathrm{ZnO}-\mathrm{TiO}_{2} / \mathrm{EG}$ & $\frac{k_{n f}}{k_{b f}}=1+0.004503 \varnothing^{0.8717} T^{0.7972}$ \\
\hline Esfahani et al. [37] & $\mathrm{ZnO}-\mathrm{Ag} /$ water & $\frac{k_{n f}}{k_{b f}}=1+0.0008974 \varnothing^{0.5899} T^{1.345}$ \\
\hline
\end{tabular}

It is important to mention here that to reach a stable hybrid nanofluid, the absolute zeta potential of the hybrid nanofluid must be increased to the extent possible. As the zeta potential diverges from the isoelectric point, strong repulsive forces develop among nanoparticles and reduce agglomeration [40].

In the next section, the thermophysical and rheological properties of the hybrid nanofluids are covered.

Furthermore, comprehensive reviews on hybrid nanofluids preparation have been conducted by Sundar et al. [38], Takabi and Salehi [39] and Babu et al. [40]. They summarized all the work that is related to the preparation of such nanofluids in recent decades.

\section{THERMOPHYSICAL PROPERTIES OF HYBRID NANOFLUIDS}

Studying the thermophysical and rheological properties of hybrid nanofluids is essential for the continuous development and determination of their usage in various applications. Furthermore, a significant amount of combination between nanofluid types can be done in preparing hybrid nanofluids.
Therefore, many researches worked on investigating thermophysical and rheological properties, in addition to the main parameters that affect hybrid nanofluids.

The density and heat capacity of hybrid nanofluids can be calculated using a mixture model, as Eqs. (1) and (2):

$$
\begin{gathered}
\rho_{h y}=\varnothing_{n p_{1}} \rho_{n p_{1}}+\ldots+\varnothing_{n p_{n}} \rho_{n p_{n}}+\left(1-\varnothing_{n p}\right) \\
c_{h y}=\frac{\varnothing_{n p_{1}} \rho_{n p_{1}} c_{n p_{1}}+\ldots+\varnothing_{n p_{n}} \rho_{n p_{n}} c \rho_{n p_{n}}+\left(1-\varnothing_{n p}\right) \rho_{b f} c_{b f}}{\rho_{h y}}
\end{gathered}
$$

where $\varnothing_{n p}$ is the volume concentration of all nanoparticles

$$
\varnothing_{n p}=\sum_{i=1}^{n} \varnothing_{n p_{i}}
$$

The thermal conductivities and viscosity of nanofluids can be predicted with traditional models, such as the Hamilton and Crosser model [41] for predicting thermal conductivity:

$$
k_{e f f}=k_{b f} \frac{k_{p}+(n-1) k_{b f}+(n+1)\left(k_{p}-k_{b f}\right) \varnothing}{k_{p}+(n-1) k_{b f}-\left(k_{p}-k_{b f}\right) \varnothing},
$$


where $n$ is the shape factor $n: 3 \leq n \leq 3.13$ and for spherical shape $n=3$.

For hybrid nanofluids, the thermal conductivity can be calculated using Eq. (5) and Batchelor correlation [42] (Eq. (6)) for the viscosity.

$$
\begin{gathered}
k_{p}=\frac{\varnothing_{n p_{1}} k_{n p_{1}}+\varnothing_{n p_{2}} k_{n p_{2}}+\ldots+k_{n p_{n}} \rho_{n p_{n}}}{\varnothing_{n p}}, \\
\mu_{e f f}=\left(1+2.5 \varnothing+6.2 \varnothing^{2}\right) \mu_{b f} .
\end{gathered}
$$

Some researchers have indicated that the viscosity and thermal conductivity of the hybrid nanofluid are very high compared to water, and even higher when compared to the theoretical correlations. Kannaiyan et al. [43] proved that the empirical correlations are inadequate when compared to the measurement values. They studied the thermophysical properties of EGwater-based $\mathrm{Al}_{2} \mathrm{O}_{3} / \mathrm{CuO}$ hybrid nanofluids at different concentrations. They revealed that conventional correlations need to consider the interfacial chemical interactions between nanomaterials and base fluids.

Correlations for specific hybrid nanofluids types depend on experimental data collection, whereby general correlations were predicted by using methods such as curve fitting, the predicted residual error sum of squares (PRESS) or any regression software. Table 2 introduces some correlations that were derived from recent experimental works. Esfe et al. [24] predicted a correlation to predict the thermal conductivity of CNTs- $\mathrm{Al}_{2} \mathrm{O}_{3}$ /water hybrid nanofluid. The effects of volume concentration and temperature were emphasized in their correlation. In the next work, Esfe et al. [32] revealed that traditional models have failed to predict the dynamic viscosity of $\mathrm{MWCNT}+\mathrm{SiO}_{2} /$ engine oil hybrid nanofluid. Furthermore, Newtonian behaviour towards the nano-lubricant was at volume fraction up to $1 \%$, and non-Newtonian are at 1.5 $\%$ and $2 \%$. These predicted correlations are very useful in numerical investigations to ensure that the simulations are more reliable, cost effective and time saving.

Recently Esfe et al. [44] studied the thermal conductivity of dispersing SWCNT and $\mathrm{ZnO}$ particles in a solution containing $30 \% \mathrm{EG}$ and $70 \%$ water. They proposed a new correlation to thermal conductivity ratio of the nanofluid. They also concluded that the thermal conductivity is more sensitive to concentration variations than to temperature changes.

Hybrid nanofluids were proven to highly enhance the effective thermal conductivity and viscosity, compared to the mono-nanofluids. Sundar et al. [21] concluded that the thermal conductivity of nano- diamond and nickel (ND-Ni)/EG enhances $21 \%$ effectively more when compared to the base fluid. They have also observed a $28.46 \%$ enhancement of MWCNT- $-\mathrm{Fe}_{3} \mathrm{O}_{4}$ /water compared to the base fluid [8]. Additionally, Suresh et al. [7] found enormous enhancement in the effective thermal conductivity and viscosity of $\mathrm{Al}_{2} \mathrm{O}_{3}-\mathrm{Cu}$ /water hybrid nanofluids in comparison to $\mathrm{Al}_{2} \mathrm{O}_{3}$ /water nanofluid. Fig. 3 indicates that as the particle concentration increased, the thermal conductivity ratio increased. The maximum enhancement of thermal conductivity was $12.1 \%$. Baghbanzadeh et al. [25] investigated the rheological properties of silica-MWCNT/water hybrid nanofluid, and the results revealed that the structure of nanomaterial is very important in enhancing the viscosity and the density despite the negative effects of MWCNT on the rheological properties development. The same finding has been concluded by Ghadikolaei et al. [45] for the thermophysical properties of $\mathrm{Tio}_{2}-$ $\mathrm{Cu} /$ water hybrid nanofluid.

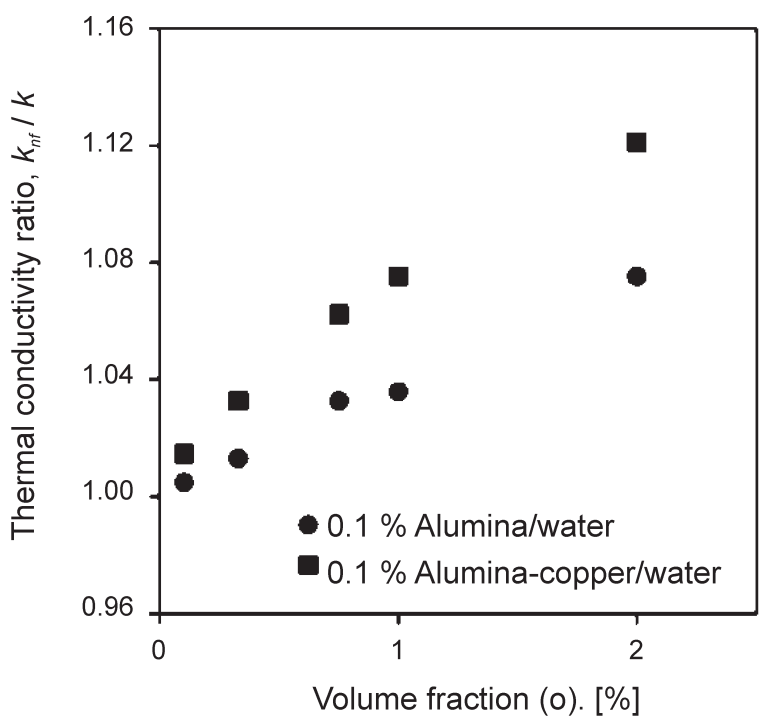

Fig. 3. Thermal conductivity ratio of the nanofluids as a function of volume concentrations [7]

Parameters that control the enhancement of the thermophysical properties of hybrid nanofluids are mainly the solid volume concentration and the temperature, in addition to the nanoparticles shapes and sizes. The Brownian motion also contributes to a great impact on this enhancement, which is even more significant when the temperature increases. This behaviour is similarly observed on mononanofluids. However, thermal conductivity is more sensitive towards the nanoparticle concentration than the temperature, contrary to the temperature effect on viscosity [34] and [46]. 
It is of great importance to mention here, based on the previous literature review, that a few research articles consider thermophysical properties to be temperature independent, such as [21] and [45]. In contrast, many research papers consider thermophysical properties to be temperature dependent, such as [7], [8], [11], [24], [25], [30], [32], [34], [36] and [37]

\section{HEAT TRANSFER ENHANCEMENT USING HYBRID NANOFLUIDS}

The main objective in studying the thermophysical properties of hybrid nanofluids is to involve and further improve its various applications, especially these related to the cooling systems such as electronic cooling, heat exchangers, and automotive cooling systems [3]. Recently, researchers had experimentally studied and numerically observed the profound effects of hybrid nanofluids in enhancing the heat transfer coefficient and reducing the pressure drop in determining the promising coolant.

Based on the literature review, one can classify the work done to investigate heat transfer enhancement using hybrid nanofluids into two major categories: numerical and experimental works. The next subsections summarize the work done that is related to the enhancement of heat transfer employing hybrid nanofluid based on the aforementioned classification.

\subsection{Numerical Studies}

Labib et al. [47] numerically investigated the convective heat transfer after adding $\mathrm{Al}_{2} \mathrm{O}_{3}$ nanoparticles to $\mathrm{CNTs} /$ water nanofluids. Their results indicated a $59.86 \%$ increase of heat transfer coefficient when utilizing ( 0.05 vol.\% CNTs +1.6 $\mathrm{Al}_{2} \mathrm{O}_{3}$ )/water compared to utilizing 0.05 vol.\% CNTs/ water. They claim that such enhancement for this combination is due to a thinner boundary layer of CNT nanofluid, which may cause significant enhancement in the convection heat transfer coefficient. The hybrid nanofluid particle concentration's effect on heat transfer performance is reflected in Fig. 4, which shows that the average heat transfer coefficient increases when the nanoparticle fraction and Reynolds number rises. Furthermore, the effects of adding low concentration of GNPs to $\mathrm{Al}_{2} \mathrm{O}_{3}$ /water nanofluid on heat transfer performance were studied numerically for different mini-tube sizes and nanoparticle volume fractions by Hussien et al. [48]. Their results noted a high enhancement in heat transfer coefficient for $\mathrm{Al}_{2} \mathrm{O}_{3}+$ graphene hybrid nanofluid over $\mathrm{Al}_{2} \mathrm{O}_{3}$ /water nanofluid with extra penalty in pressure drop. Fig. 5 clearly indicates the increment in pressure drop for hybrid nanofluid over mono-nanofluid.

Takabi and Shokouhmand [49] numerically analysed the turbulent forced convective heat transfer of $\mathrm{Al}_{2} \mathrm{O}_{3}-\mathrm{Cu} /$ water hybrid nanofluid. Uniform heat flux was applied on the external walls of circular tubes. They compared the results obtained from hybrid nanofluid with $\mathrm{Al}_{2} \mathrm{O}_{3}$ /water nanofluid, and hybrid nanofluid with water. Their results show that the use of hybrid nanofluids could increase the average Nusselt number; however, the increase in pressure drop is one of the main obstacles.

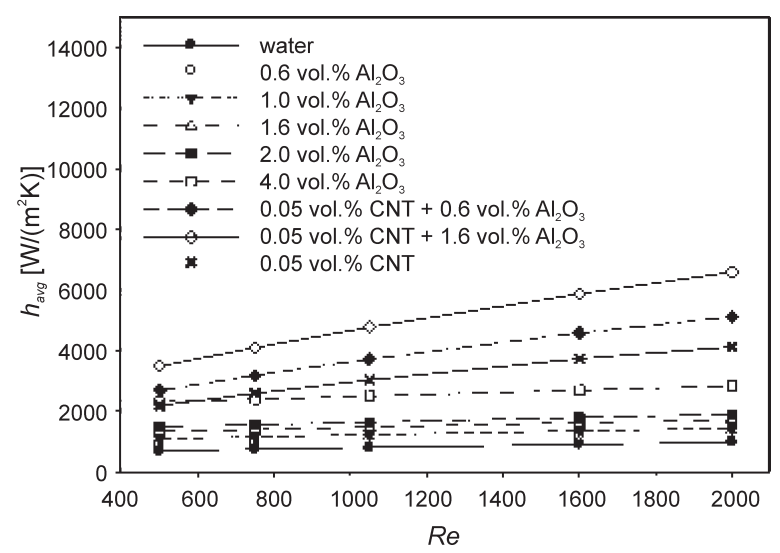

Fig. 4. Effect of particle concentration and Reynolds number of average heat transfer coefficient of mono and hybrid nanofluids [47]

Takabi at el. [50] used the same hybrid nanofluid to investigate the thermal effect in the laminar regime and found a $7.2 \%$ enhancement in the average Nusselt number compared to water, with only a 10.94 $\%$ increase in the pressure drop.

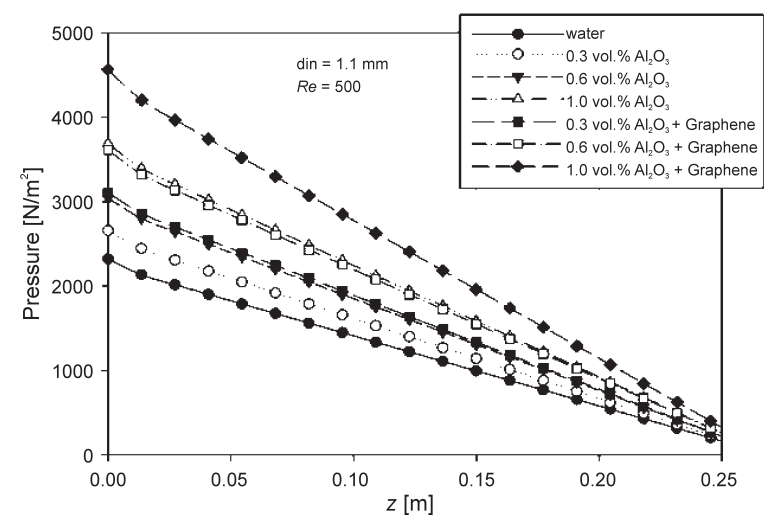

Fig. 5. The effect of hybrid nanofluid on the pressure drop [48]

Nimmagadda and Venkatasubbaiah [51] shared their results, which reflect an enormous enhancement 
in the heat transfer coefficient, reaching up to $148 \%$. They used 3 vol. $\% \mathrm{Al}_{2} \mathrm{O}_{3}+\mathrm{Ag} /$ water hybrid nanofluid flow inside a wide microchannel in the laminar regime. In another numerical study, they investigated the effects of $\mathrm{SWCNT}+\mathrm{Cu} /$ water hybrid nanofluid in convective heat transfer enhancement [52]. A study by Moghadassi et al. [53] showed that there is an enhancement in the convective heat transfer of $\mathrm{Al}_{2} \mathrm{O}_{3}+\mathrm{Cu} /$ water, hybrid nanofluid flow inside a circular tube under uniform heat flux when compared to nanofluid. The flow in the study was assumed to be laminar $(\operatorname{Re}<2300)$, and the results were compared to the same concentration of $\mathrm{Al}_{2} \mathrm{O}_{3} /$ water nanofluid. Their results revealed that by adding $\mathrm{Cu}$ nanoparticles, there was a $4.73 \%$ increase in heat transfer. Balla et al. [54] had determined the heat transfer coefficient for the laminar flow of the $\mathrm{Cu}+\mathrm{CuO} /$ water hybrid nanofluid in a circular tube. The combination of metallic and metal oxide nanoparticles was used and experimented with different ratio and different volume concentrations of hybrid nanofluids. Their results illustrated a $30 \%$ to $35 \%$ enhancement of the Nusselt number ratio with a noticeable pressure drop. The pressure drop was also increased with the increase of the Reynolds number, the volume concentration of nanoparticles, and the density of nanoparticle materials. In addition, Takabi and Salehi [39] concluded that the heat transfer performance can be augmented utilizing hybrid nanofluid for laminar natural convection in a sinusoidal corrugated enclosure.

\subsection{Experimental Studies}

Sundar et al. [55] experimentally studied the effects of hybrid nanofluid concentration on both heat transfer and friction factors. The MWCNT- $\mathrm{Fe}_{3} \mathrm{O}_{4}$ nanocomposite particles were used in preparing hybrid nanofluids in different volume concentrations ( 0 vol. $\%$ to 0.3 vol.\%). The results highlight the increase of Nusselt number dependent on the increase of particle concentration. Fortunately, a negligible increase in the friction factor was observed.

Zubir et al. [56] used the reduced graphene oxide (RGO), and its hybrid complexes were employed to improve the convective heat transfer performance. They applied a turbulent flow of hybrid complexes solutions inside a closed conduit and observed the heat transfer performance. They recorded a profound enhancement in the Nusselt number that reached 144 $\%$, due to the increase in thermal conductivity. Safaei et al. [57] examined the heat transfer performance when different concentrations of graphene nanoplatelets-silver hybrid nanofluids were used as a coolant. The Reynolds number range used was 5,000 $\leq R e \leq 15,000$ within a fully developed turbulent flow regime. The outcome indicates an improvement in heat transfer performance with an increase of required pumping power to overcome pressure drop.

Recently, Hussien et al. [58] to [60] studied the thermal performance of MWCNTs/water nanofluid and MWCNTs/GNPs hybrid nanofluid in minitubes. Their experimental results show high enhancement of heat transfer coefficients with an increase in pressure drop when using a low weight concentration of MWCNTs/GNPs. They concluded that the increase in pressure drop is insignificant when compared to the gain of the enhancement of heat transfer. Yarmand et al. [61] investigated turbulent forced convective heat transfer for GNP-Platinum (Pt) hybrid nanofluids. Their experimental results reveal that the heat transfer enhancement is dependent on the concentration of the nanocomposite in addition to Reynolds number. Sundar et al. [13] studied the turbulent heat transfer and pressure drop of ND-Ni hybrid nanofluids through a horizontal tube. They found that hybrid nanofluids enhanced heat transfer better than mono nanofluids.

Hamid et al. [62] experimentally investigated the role of $\mathrm{TiO}_{2}-\mathrm{SiO}_{2}$ /water hybrid nanofluids on improving heat transfer performance. Different composite mixture ratios were used under turbulent flow. The highest performance noted was $35.32 \%$ with a negligible pressure drop.

The configuration of the hybrid nanoparticles on the base fluids leads to the generation of high thermal conductivity of the hybrid nanofluid. This superior thermal conductivity increases the ability of working fluid to transfer heat with the surroundings.

In contrast, the continuous movement of nanoparticles in the base fluid, specially at the layers near the walls, increases the chance of collision with the wall required for heat transfer.

In summary, the heat transfer enhancement using hybrid nanofluids depends mainly on nanoparticles concentrations, nanoparticles types, and Reynolds number. From the previous literature review and various research works, it is clear that improvement of the heat transfer will unavoidably be combined with a penalty in terms of pressure drop.

\section{THERMAL APPLICATIONS OF HYBRID NANOFLUIDS}

The use of mono-nanofluids to increase cooling efficiency in various energy applications plays a vital role in obtaining optimal design along with significant improvement in operation systems, which can have 
great impact on thermal applications, leading to magnificent performance in system by using mono nanofluids such as heat exchangers [63], heat pipes [64], cooling electronic devices [65] and [66], and automotive cooling system [67] and [68].

Thermal performance improvement using hybrid nanofluids is in great demand for two reasons. Firstly, there are many other applications that are waiting to be tested, such as automotive cooling systems, solar cells, types of heat exchangers, and mini/micro channels. Secondly (despite all existing studies) there are still a massive number of possible combinations that can be made from nanoparticle materials, which can be used in future studies.

In their experimental research, Selvakumar and Suresh [18] used $\mathrm{Al}_{2} \mathrm{O}_{3}-\mathrm{Cu} /$ water hybrid nanofluid for the cooling of electrical components through a thin-channelled copper heat sink. Fig. 6 show the photographs of copper heat sink with jet plate. Their results reflect a significant enhancement in heat transfer coefficient for hybrid nanofluid compared to water. Pressure drop also increased, although the increase is less than the increase in heat transfer coefficient. Therefore, they recommended the use of hybrid nanofluids as a coolant. Based on this reason, most of the main investigations nowadays emphasize observations along with the utilizations of hybrid nanofluids.

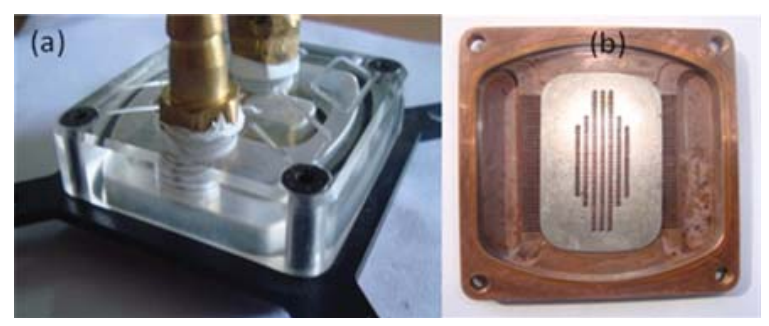

Fig. 6. a) Photograph of heat sink, and

b) thin-channeled copper base with jet plate [18]

Bahiraei and Heshmatian [66] utilized hybrid nanofluid that contains graphene nanoplatelets decorated with silver nanoparticles in a CPU cooler. Their results show a higher thermal performance and irreversibility rates than a normal CPU cooler. They strongly suggest hybrid nanofluids as a promising coolant for electrical devices.

Sozen et al. [69] studied the role of fly ash water-based nanofluid in increasing the efficiency of a concentric tube heat exchanger. They prepared 2 wt.\% nanofluid through direct synthesis. The maximum improvement of the efficiency was 31.2 $\%$ for a parallel flow concentric tube heat exchanger.
Safi et al. [19] investigated experimentally the use of MWCNT- $\mathrm{TiO}_{2} /$ water hybrid nanofluid in a plate heat exchanger (PHE) where the heat transfer performance was studied. There was a $20.2 \%$ increase in the heat transfer coefficient compared with water, and this increase depends on the particle concentration and inlet temperature. In addition Madhesh and Kalaiselvam [70] concluded that an enhancement of heat transfer coefficient also occurred when using $\mathrm{Cu}-\mathrm{TiO}_{2} /$ water hybrid nanofluid, after testing it as a coolant inside a tubular heat exchanger. The heat transfer coefficient was enhanced by $48.4 \%$ compared with water. In their study, 0.1 vol. $\%$ to 1 vol.\% nanocomposite volume concentrations were utilized. Most importantly, they had concluded that the development of thermal conductivity and diffusion kinetic of hybrid nanofluids are the main causes of heat transfer coefficient enhancement.

Recently, Huang et al. [31] investigated the new application for testing $\mathrm{Al}_{2} \mathrm{O}_{3}+\mathrm{MWCNT} /$ water hybrid nanofluid in a plate heat exchanger. In that experiment, a mixture of $0.0111 \% \mathrm{MWCNT} /$ water nanofluid with $1.89 \% \mathrm{Al}_{2} \mathrm{O}_{3} /$ water nanofluid was used, and a very low enhancement in heat transfer coefficient compared to $\mathrm{Al}_{2} \mathrm{O}_{3}$ /water with a slight increase in pressure drop was subsequently detected. Since these results may contradict previous research, it was considered erroneous because the enhancement is within the range of experimental errors. However, it was still recommended that hybrid nanofluids be used in heat transfer applications.

To improve engine oil as a coolant and lubricant fluid, Asadi et al. [68] added $\mathrm{Mg}(\mathrm{OH})_{2} / \mathrm{MWCNT}$ to engine oil. Their results showed an increase in viscosity and thermal conductivity with a rise in nanomaterials concentration. Therefore, hybrid nano-lubricant could be adopted as a lubricant fluid. The hybrid nanofluids were also used to improve the thermal resistance of a cylindrical screen mesh heat pipe by Ramachandran et al. [29] and [71]. They combined $\mathrm{Al}_{2} \mathrm{O}_{3}$ and $\mathrm{CuO}$ nanoparticles in different ratios and obtained results showing a $44.25 \%$ maximum reduction in thermal resistance for the ratio $\mathrm{Al}_{2} \mathrm{O}_{3} 25 \%$ and $\mathrm{CuO} 75 \%$. Based on the results, it can be concluded that hybrid nanofluids should be strongly considered as a substitute for conventional fluid.

Moreover, nanofluids and hybrid nanofluids are used to enhance the performance of solar energy. For instance, Shah and Ali [72] presented a critical review on applications of hybrid nanofluids in solar energy along with practical limitations and challenges. They also discussed the economics and ecology of 
nanofluid-based solar systems. In addition, Hader and Al-Kouz [73] numerically investigated the effect of dispersing nanosolid particles in a hybrid photovoltaic/ thermal system. It was shown that dispersing such particles will enhance the overall efficiency of the hybrid system but with a pressure drop penalty. Furthermore, Jin et al. [74] investigated experimentally and numerically the solar photothermal conversion characteristics of hybrid nanofluids. They concluded that hybrid nanofluids with different absorption peaks can enhance efficiency. They also found that there is an optimal mixing volume fraction for hybrid nanofluids.

Finally, a comprehensive review of the recent progress on hybrid nanofluids in heat transfer applications is presented in [75] and [76].

It is worth mentioning here that few research studies had been conducted on dispersing nanofluid in rarefied gases. For instance, Al-Kouz et al. [77] investigated the effect of dispersing nanosolid particles of $\mathrm{Al}_{2} \mathrm{O}_{3}$ into the air base fluid in cavities equipped with solid fins. The effects of Knudsen number, volume fraction of the nanosolid particles, Rayleigh number on both heat transfer and pressure drop were analysed. It was shown that dispersing nanosolid particles enhances the heat transfer but with a pressure drop penalty. Their results were compared to Al-Kouz et al. [78] to show the enhancement in heat transfer compared to rarefied flows with no dispersed solid particles. Moreover, Al-Kouz et al. [79] studied the entropy generation inside cavities equipped with solid fins and filled with air $/ \mathrm{Al}_{2} \mathrm{O}_{3}$ nanofluid. The effects of Knudsen number and volume fraction of the nanosolid particles on the total entropy generation were shown and analysed. In addition, the correlation for the total entropy generation among all the investigated parameters is proposed. Finally, Al-Kouz et al. [80] conducted a numerical study to investigate heat transfer characteristics in the entrance region of laminar rarefied air $/ \mathrm{Al}_{2} \mathrm{O}_{3}$ flow in pipes. The effects of the aspect ratio, Knudsen number, Reynolds number and the nanosolid particle volume fraction on the heat transfer characteristics were presented, and a correlation of Nusselt number among all the investigated parameters is introduced. Investigating rarefied flows with hybrid nanofluids, which has not been done yet to the authors' knowledge, is highly recommended.

\section{CONCLUSION}

This article constitutes a brief review of the preparation and heat transfer enhancement of hybrid nanofluids. Recent publications that deal with preparation, synthesis, thermophysical properties, experimental aspects and numerical studies of hybrid nanofluids in thermal applications were summarized. The main reasons behind the enhanced performance of heat transfer in hybrid nanofluids is the improved effective thermal conductivity and kinetic motion of nanoparticles. Despite the enhanced heat transfer of hybrid nanofluids, many challenges, penalties and obstacles are facing designers and researches working in this field. For instance, higher pumping power is needed to overcome pressure drop, stability analysis, the effect of sizes and shapes of nanocomposite materials as well as identifying the mechanisms for thermal and rheological properties enhancement. These challenges should be viewed as opportunities to carry out more research. Finally, more effort is required in determining use of hybrid nanofluids to serve as a promising coolant in industrial sector.

\section{NOMENCLATURE}

$k$ thermal conductivity, $[\mathrm{W} /(\mathrm{m} \cdot \mathrm{K})]$

$c_{p} \quad$ specific heat capacity, $[\mathrm{J} /(\mathrm{kg} \cdot \mathrm{K})]$

Re Reynolds number, [-]

$T$ bulk fluid temperature, $[\mathrm{K}]$

$\mu \quad$ dynamic viscosity, $\left[\mathrm{N} \cdot \mathrm{s} / \mathrm{m}^{2}\right]$

$\varphi \quad$ nanoparticles volume fraction, [vol.\%]

$\rho$ density, $\left[\mathrm{kg} / \mathrm{m}^{3}\right]$

Subscripts

bf base fluid,

nf nanofluid,

hy hybrid nanofluids,

$n p$ nanoparticles,

eff effective.

\section{REFERENCES}

[1] Chol, S. (1995). Enhancing Thermal Conductivity of Fluids with Nanoparticles. ASME International Mechanical Engineering Congress and Exposition, p. 99-106.

[2] Hussien, A.A., Abdullah, M.Z., Al-Nimr, M. (2016). Single-phase heat transfer enhancement in micro/minichannels using nanofluids: Theory and applications, Applied Energy, vol. 164, p. 733-755, DOI:10.1016/j.apenergy.2015.11.099.

[3] Sarkar, J., Ghosh, P., Adil, A. (2015). A review on hybrid nanofluids: Recent research, development and applications. Renewable and Sustainable Energy Reviews, vol. 43, p. 164177, D0I:10.1016/j.rser.2014.11.023.

[4] Rajput, N. (2015). Methods of preparation of nanoparticles-a review. International Journal of Advances in Engineering \& Technology, vol. 7, no. 4, p. 1806-1811. 
[5] Ma, B., Banerjee, D. (2018). A Review of Nanofluid Synthesis. Advances in Nanomaterials, Springer, Cham, p. 135-176, D0I:10.1007/978-3-319-64717-3_6.

[6] Jena, P., Brocchi, E.A., Motta, M.S. (2001). In-situ formation of $\mathrm{Cu}-\mathrm{Al} 203$ nano-scale composites by chemical routes and studies on their microstructures. Materials Science and Engineering: A, vol. 313, no. 1-2, p.180-186, D0l:10.1016/ S0921-5093(00)01998-5.

[7] Suresh, S., Venkitaraj, K.P., Selvakumar, P., Chandrasekar, M. (2011). Synthesis of Al203-Cu/water hybrid nanofluids using two step method and its thermophysical properties. Colloids and Surfaces A: Physicochemical and Engineering Aspects, vol. 388, p. 1-3, p. 41-48, D0l:10.1016/j.colsurfa.2011.08.005.

[8] Sundar, L.S., Singh, M.K., Sousa, A.C.M. (2014). Enhanced heat transfer and friction factor of MWCNT-Fe304/water hybrid nanofluids. International Communications in Heat and Mass Transfer, vol. 52, p. 73-83, D0l:10.1016/j. icheatmasstransfer.2014.01.012.

[9] Yarmand, H., Gharehkhani, S., Ahmadi, G., Shirazi, S.F.S., Baradaran, S., Montazer, E., Zubir, M.N.M., Alehashem, M.S., Kazi, S.N., Dahari, M. (2015). Graphene nanoplateletssilver hybrid nanofluids for enhanced heat transfer. Energy Conversion and Management, vol. 100, p. 419-428, D0l:10.1016/j.enconman.2015.05.023.

[10] Megatif, L., Ghozatloo, A., Arimi, A., Shariati-Niasar, M. (2016). Investigation of laminar convective heat transfer of a novel $\mathrm{TiO}_{2}$-Carbon nanotube hybrid water-based nanofluid. Experimental Heat Transfer, vol. 29, no. 1, p. 124-138, DOl:10.1080/08916152.2014.973974.

[11] Harandi, S.S., Karimipour, A., Afrand, M., Akbari, M., D'Orazio, A. (2016). An experimental study on thermal conductivity of F-MWCNTs-Fe304/EG hybrid nanofluid: Effects of temperature and concentration. International Communications in Heat and Mass Transfer, vol. 76, p. 171177, D0l:10.1016/j.icheatmasstransfer.2016.05.029.

[12] Akilu, S., Baheta, A.T., Sharma, K. (2017). Experimental measurements of thermal conductivity and viscosity of ethylene glycol-based hybrid nanofluid with $\mathrm{TiO}_{2}$-CuO/C inclusions. Journal of Molecular Liquids, vol. 246, p. 396-405, DOl:10.1016/j.molliq.2017.09.017.

[13] Sundar, L.S., Singh, M.K., Sousa, A.C.M. (2018). Turbulent heat transfer and friction factor of nanodiamond-nickel hybrid nanofluids flow in a tube: An experimental study. International Journal of Heat and Mass Transfer, vol. 117, p. 223-234, DOl:10.1016/j.ijheatmasstransfer.2017.09.109.

[14] Han, Z.H., Yang, B., Kim, S.H., Zachariah, M.R. (2007). Application of hybrid sphere/carbon nanotube particles in nanofluids. Nanotechnology, vol. 18, no. 10, art. ID 105701, DOI:10.1088/0957-4484/18/10/105701.

[15] Chen, L., Yu, W., Xie, H. (2012). Enhanced thermal conductivity of nanofluids containing Ag/MWNT composites. Powder Technology, vol. 231, p. 18-20, D0l:10.1016/j. powtec.2012.07.028.

[16] Suresh, S., Venkitaraj, K.P., Selvakumar, P., Chandrasekar, M. (2012). Effect of Al203-Cu/water hybrid nanofluid in heat transfer. Experimental Thermal and Fluid Science, vol. 38, p. 54-60, D0I:10.1016/j.expthermflusci.2011.11.007.
[17] Khosravifard, E., Salavati-Niasari, M., Dadkhah, M., Sodeifian, Gh. (2012). Synthesis and characterization of Ti02-CNTs nanocomposite and investigation of viscosity and thermal conductivity of a new nanofluid. Journal of Nanostructures, vol. 2, no. 2, p. 191-197, Dol:10.7508/JNS.2012.02.006.

[18] Selvakumar, P., Suresh, S. (2012). Use of Al203-Cu/ Water Hybrid Nanofluid in an Electronic Heat Sink. IEEE Transactions on Components, Packaging and Manufacturing Technology, vol. 2, no. 10, p. 1600-1607, D0l:10.1109/ TCPMT.2012.2211018.

[19] Safi, M.A., Ghozatloo, A., Hamidi, A.A., Shariaty-Niassar, M. (2014). Calculation of heat transfer coefficient of MWCNT-TiO2 nanofluid in plate heat exchanger. International Journal of Nanoscience and Nanotechnology, vol. 10, no. 3, p. 153-162.

[20] Nine, Md.J., Batmunkh, M., Kim, J.-H., Chung, H.-S., Jeong, H.M. (2012). Investigation of Al203-MWCNTs hybrid dispersion in water and their thermal characterization. Journal of Nanoscience and Nanotechnology, vol. 12, no. 6, p. 45534559, DOI:10.1166/jnn.2012.6193.

[21] Sundar, L.S., Singh, M.K., Ramana, E.V., Singh, B., Grácio, J., Sousa, A.C. (2014). Enhanced thermal conductivity and viscosity of nanodiamond-nickel nanocomposite nanofluids. Scientific Reports, vol. 4, 4039, p. 1-14, D0l:10.1038/ srep04039.

[22] Madhesh, D., Parameshwaran, R., Kalaiselvam, S. (2014). Experimental investigation on convective heat transfer and rheological characteristics of $\mathrm{Cu}-\mathrm{TiO}_{2}$ hybrid nanofluids. Experimental Thermal and Fluid Science, vol. 52, p. 104-115, D0I:10.1016/j.expthermflusci.2013.08.026.

[23] Esfe, M.H., Arani, A.A.A., Rezaie, M., Yan, W.-M., Karimipour, A. (2015). Experimental determination of thermal conductivity and dynamic viscosity of Ag-MgO/water hybrid nanofluid. International Communications in Heat and Mass Transfer, vol. 66, p. 189-195, D0l:10.1016/j. icheatmasstransfer.2015.06.003.

[24] Esfe, M.H., Saedodin, S., Biglari, M., Rostamian, H. (2015). Experimental investigation of thermal conductivity of CNTs- $\mathrm{Al}_{2} \mathrm{O}_{3}$ /water: a statistical approach. International Communications in Heat and Mass Transfer, vol. 69, p. 29-33, D0I:10.1016/j.icheatmasstransfer.2015.10.005.

[25] Baghbanzadeh, M., Rashidi, A., Soleimanisalim, A.H., Rashtchian, D. (2014). Investigating the rheological properties of nanofluids of water/hybrid nanostructure of spherical silica/MWCNT. Thermochimica Acta, vol. 578, p. 53-58, DOI:10.1016/j.tca.2014.01.004.

[26] Sundar, L.S., Sousa, A.C., Singh, M.K. (2015). Heat transfer enhancement of low volume concentration of carbon nanotube- $\mathrm{Fe}_{3} \mathrm{O}_{4} /$ water hybrid nanofluids in a tube with twisted tape inserts under turbulent flow. Journal of Thermal Science and Engineering Applications, vol. 7, no. 2, 021015, Dol:10.1115/1.4029622.

[27] Madhesh, D., Parameshwaran, R., Kalaiselvam, S. (2016). Experimental studies on convective heat transfer and pressure drop characteristics of metal and metal oxide nanofluids under turbulent flow regime. Heat Transfer Engineering, vol. 37, no. 5, p. 422-434, DOl:10.1080/01457632.2015.1057448.

[28] Eshgarf, H., Afrand, M. (2016). An experimental study on rheological behavior of non-Newtonian hybrid nano-coolant 
for application in cooling and heating systems. Experimental Thermal and Fluid Science, vol. 76, p. 221-227, D0l:10.1016/j. expthermflusci.2016.03.015.

[29] Ramachandran, R., Ganesan, K., Rajkumar, M., Asirvatham, L., Wongwises, S. (2016). Comparative study of the effect of hybrid nanoparticle on the thermal performance of cylindrical screen mesh heat pipe. International Communications in Heat and Mass Transfer, vol. 76, p. 294-300, D0l:10.1016/j. icheatmasstransfer.2016.05.030.

[30] Asadi, M., Asadi, A. (2016). Dynamic viscosity of MWCNT/ ZnO-engine oil hybrid nanofluid: an experimental investigation and new correlation in different temperatures and solid concentrations. International Communications in Heat and Mass Transfer, vol. 76, p. 41-45, D0l:10.1016/j. icheatmasstransfer.2016.05.019.

[31] Huang, D., Wu, Z., Sunden, B. (2016). Effects of hybrid nanofluid mixture in plate heat exchangers. Experimental Thermal and Fluid Science, vol. 72, p. 190-196, D0l:10.1016/j. expthermflusci.2015.11.009.

[32] Esfe, M.H., Afrand, M., Yan, W.M., Yarmand, H., Toghraie, D., Dahari, M. (2016). Effects of temperature and concentration on rheological behavior of MWCNTS/SiO 2 (20-80)-SAE40 hybrid nano-lubricant. International Communications in Heat and Mass Transfer, vol. 76, p. 133-138, D0l:10.1016/j. icheatmasstransfer.2016.05.015.

[33] Afrand, M., Toghraie, D., Ruhani, B. (2016). Effects of temperature and nanoparticles concentration on rheological behavior of $\mathrm{Fe}_{3} \mathrm{O}_{4}-\mathrm{Ag} / \mathrm{EG}$ hybrid nanofluid: An experimental study. Experimental Thermal and Fluid Science, vol. 77, p. 3844, D0I:10.1016/j.expthermflusci.2016.04.007.

[34] Afrand, M., Najafabadi, K.N., Akbari, M. (2016). Effects of temperature and solid volume fraction on viscosity of $\mathrm{SiO}_{2}$ MWCNTs/ $\mathrm{SAE}_{4} \mathrm{O}$ hybrid nanofluid as a coolant and lubricant in heat engines. Applied Thermal Engineering, vol. 102, p. 4554, D0I:10.1016/j.applthermaleng.2016.04.002.

[35] Allahyar, H.R., Hormozi, F., ZareNezhad, B. (2016). Experimental investigation on the thermal performance of a coiled heat exchanger using a new hybrid nanofluid. Experimental Thermal and Fluid Science, vol. 76, p. 324-329, D0I:10.1016/j.expthermflusci.2016.03.027.

[36] Toghraie, D., Chaharsoghi, V.A., Afrand, M. (2016). Measurement of thermal conductivity of $\mathrm{ZnO}$-TiO2/EG hybrid nanofluid. Journal of Thermal Analysis and Calorimetry, vol. 125, no. 1, p. 527-535, D0l:10.1007/s10973-016-5436-4.

[37] Esfahani, N.N., Toghraie, D., Afrand, M. (2018). A new correlation for predicting the thermal conductivity of $\mathrm{ZnO}-\mathrm{Ag}$ (50\%-50\%)/water hybrid nanofluid: an experimental study. Powder Technology, vol. 323, p. 367-373, D0l:10.1016/j. powtec.2017.10.025.

[38] Sundar, L.S., Sharma, K., Singh, M.K., Sousa, A. (2017). Hybrid nanofluids preparation, thermal properties, heat transfer and friction factor - A review. Renewable and Sustainable Energy Reviews, vol. 68, p. 185-198, D0l:10.1016/j.rser.2016.09.108.

[39] Takabi, B., Salehi, S. (2014). Augmentation of the heat transfer performance of a sinusoidal corrugated enclosure by employing hybrid nanofluid. Advances in Mechanical Engineering, vol. 6, 147059, p. 1-16, Dol:10.1155/2014/147059.
[40] Babu, J.A.R., Kumar, K.K., Rao, S.S. (2017). State-of-art review on hybrid nanofluids. Renewable and Sustainable Energy Reviews, vol. 77, p. 551-565, Dol:10.1016/j.rser.2017.04.040.

[41] Hamilton, R., Crosser, O. (1962). Thermal conductivity of heterogeneous two-component systems. Industrial \& Engineering Chemistry Fundamentals, vol. 1, no. 3, p. 187191, D0I:10.1021/i160003a005.

[42] Batchelor, G. (1977). The effect of Brownian motion on the bulk stress in a suspension of spherical particles. Journal of Fluid Mechanics, vol. 83, no. 1, p. 97-117, Dol:10.1017/ S0022112077001062.

[43] Kannaiyan, S., Boobalan, C., Umasankaran, A., Ravirajan, A., Sathyan, S., Thomas, T. (2017). Comparison of experimental and calculated thermophysical properties of alumina/cupric oxide hybrid nanofluids. Journal of Molecular Liquids, vol. 244, p. 469-477, D0l:10.1016/j.molliq.2017.09.035.

[44] Esfe, M.H., Arani, A.A.A., Firouzi, M. (2017). Empirical study and model development of thermal conductivity improvement and assessment of cost and sensitivity of EG-water based SWCNTZn0 (30\%:70\%) hybrid nanofluid. Journal of Molecular Liquids, vol. 244, p. 252-261, D0l:10.1016/j.molliq.2017.08.087.

[45] Ghadikolaei, S.S., Yassari, M., Sadeghi, H., Hosseinzadeh, Kh., Ganji, D.D. (2017). Investigation on thermophysical properties of $\mathrm{TiO} 2-\mathrm{Cu} / \mathrm{H} 2 \mathrm{O}$ hybrid nanofluid transport dependent on shape factor in MHD stagnation point flow. Powder technology, vol. 322, p. 428-438, D0l:10.1016/j.powtec.2017.09.006.

[46] Ebrahimi, S., Saghravani, S.F. (2017). Experimental study of the thermal conductivity features of the water based Fe304/ CuO nanofluid. Heat and Mass Transfer, vol. 54, no. 4, p. 9991008, D0I:10.1007/s00231-017-2188-z.

[47] Labib, M.N., Nine, M.J., Afrianto, H., Chung, H., Jeong, H. (2013). Numerical investigation on effect of base fluids and hybrid nanofluid in forced convective heat transfer. International Journal of Thermal Sciences, vol. 71, p. 163-171, D0l:10.1016/j.jithermalsci.2013.04.003.

[48] Hussien, A.A., Yusop, N.M., Moh'd A,A.N., Abdullah, M. Z., Janvekar, A.A., Elnaggar, M. H. (2019). Numerical study of heat transfer enhancement using $\mathrm{Al}_{2} \mathrm{O}_{3}$-graphene/water hybrid nanofluid flow in mini tubes. Iranian Journal of Science and Technology, Transactions A: Science, vol. 43, no. 4, p. 1989 200, DOI:10.1007/s40995-018-0670-1.

[49] Takabi, B., Shokouhmand, H. (2015). Effects of Al203$\mathrm{Cu} /$ water hybrid nanofluid on heat transfer and flow characteristics in turbulent regime. International Journal of Modern Physics C, vol. 26, no. 4, ID. 1550047, D0I:10.1142/ S0129183115500473.

[50] Takabi, B., Gheitaghy, A.M., Tazraei, P. (2016). Hybrid waterbased suspension of al203 and cu nanoparticles on laminar convection effectiveness. Journal of Thermophysics and Heat Transfer, vol. 30, no. 3, p. 523-532, D0l:10.2514/1.T4756.

[51] Nimmagadda, R., Venkatasubbaiah, K. (2015). Conjugate heat transfer analysis of micro-channel using novel hybrid nanofluids $\left(\mathrm{Al}_{2} \mathrm{O}_{3}+\mathrm{Ag} /\right.$ Water $)$. European Journal of Mechanics-B/Fluids, vol. 52, p. 19-27, Dol:10.1016/j. euromechflu.2015.01.007.

[52] Nimmagadda, R., Venkatasubbaiah, K. (2015). Multiphase approach on heat transfer performance of micro-channel using hybrid carbon nanofluid. ASME $13^{\text {th }}$ International 
Conference on Nanochannels, Microchannels, and Minichannels, International Technical Conference and Exhibition on Packaging and Integration of Electronic and Photonic Microsystems, ID V001T004A050, D0I:10.1115/ ICNMM2015-48117.

[53] Moghadassi, A., Ghomi, E., Parvizian, F. (2015). A numerical study of water based Al203 and Al203-Cu hybrid nanofluid effect on forced convective heat transfer. International Journal of Thermal Sciences, vol. 92, p. 50-57, D0l:10.1016/j. ijthermalsci.2015.01.025.

[54] Balla, H.H., Abdullah, S., MohdFaizal, W., Zulkifli, R., Sopian, K. (2013). Numerical study of the enhancement of heat transfer for hybrid Cu0-Cu nanofluids flowing in a circular pipe. Journal of Oleo Science, vol. 62, no. 7, p. 533-539, D0l:10.5650/ jos.62.533.

[55] Sundar, L.S., Otero-Irurueta, G., Singh, M.K., Sousa, A.C. (2016). Heat transfer and friction factor of multi-walled carbon nanotubes $-\mathrm{Fe}_{3} \mathrm{O}_{4}$ nanocomposite nanofluids flow in a tube with/without longitudinal strip inserts. International Journal of Heat and Mass Transfer, vol. 100, p. 691-703, D0l:10.1016/j. ijheatmasstransfer.2016.04.065.

[56] Zubir, M.N.M., Badarudin, A., Kazi, S.N., Huang, N.M., Misran, M., Sadeghinezhad, E., Mehrali, M., Syuhada, N.I., Gharehkhani, S. (2015). Experimental investigation on the use of reduced graphene oxide and its hybrid complexes in improving closed conduit turbulent forced convective heat transfer. Experimental Thermal and Fluid Science, vol. 66, p. 290-303, D0I:10.1016/J.expthermflusci.2015.03.022.

[57] Safaei, M.R., Ahmadi, G., Goodarzi, M.S., Safdari Shadloo, M., Goshayeshi, H.R., Dahari, M. (2016). Heat transfer and pressure drop in fully developed turbulent flows of graphene nanoplatelets-silver/water nanofluids. Fluids, vol. 1, no. 3, 20. p. 1-12, D0I:10.3390/fluids1030020.

[58] Hussien, A.A., Abdullah, M.Z., Yusop, N.M., Al-Nimr, M.A., Atieh, M.A., Mehrali, M. (2017). Experiment on forced convective heat transfer enhancement using MWCNTs/GNPs hybrid nanofluid and mini-tube. International Journal of Heat and Mass Transfer, vol. 115, p. 1121-1131, D0l:10.1016/j. ijheatmasstransfer.2017.08.120.

[59] Hussien, A.A., Yusop, N.M., Abdullah, M.Z., AL-Nimr, M.A., Khavarian, M. (2019). Study on convective heat transfer and pressure drop of MWCNTs/water nanofluid in mini-tube. Journal of Thermal Analysis and Calorimetry, vol. 135, no. 1, p. 123-132, DOl:10.1007/s10973-018-7234-7.

[60] Hussien, A.A., Abdullah, M.Z., Yusop, N.M., Al-Kouz, W., Mahmoudi, E., Mehrali, M. (2019). Heat transfer and entropy generation abilities of MWCNTS/GNPs hybrid nanofluids in microtubes. Entropy, vol. 21, no. 5, 480, D0l:10.3390/ e21050480.

[61] Yarmand, H., Zulkifli, N.W.B.M., Gharehkhani, S., Shirazi, S.F.S., Alrashed, A.A.A.A., Ali, M.A.B., Dahari, M., Kazi, S.N. (2017). Convective heat transfer enhancement with graphene nanoplatelet/platinum hybrid nanofluid. International Communications in Heat and Mass Transfer, vol. 88, p. 120125, D0l:10.1016/j.icheatmasstransfer.2017.08.010.

[62] Hamid, K.A., Azmi, W.H., Nabil, M.F., Mamat, R. (2018). Experimental investigation of nanoparticle mixture ratios on $\mathrm{TiO}_{2}-\mathrm{SiO}_{2}$ nanofluids heat transfer performance under turbulent flow. International Journal of Heat and Mass Transfer, vol. 118, p. 617-627, D0l:10.1016/j. ijheatmasstransfer.2017.11.036.

[63] Stogiannis, I.A., Mouza, A.A, Paras, S.V. (2015). Efficacy of $\mathrm{SiO}_{2}$ nanofluids in a miniature plate heat exchanger with undulated surface. International Journal of Thermal Sciences, vol. 92, p. 230-238, Dol:10.1016/j.ijthermalsci.2015.01.035.

[64] Menlik, T., Sözen, A., Gürü, M., Öztaş, S. (2015). Heat transfer enhancement using $\mathrm{MgO} /$ water nanofluid in heat pipe. Journal of the Energy Institute, vol. 88, no. 3, p. 247-257, D0I:10.1016/j.joei.2014.10.001.

[65] Ghasemi, S.E., Ranjbar, A.A., Hosseini, M.J. (2017). Experimental evaluation of cooling performance of circular heat sinks for heat dissipation from electronic chips using nanofluid. Mechanics Research Communications, vol. 84, p. 85-89, D0I:10.1016/j.mechrescom.2017.06.009.

[66] Bahiraei, M., Heshmatian, S. (2017). Efficacy of a novel liquid block working with a nanofluid containing graphene nanoplatelets decorated with silver nanoparticles compared with conventional CPU coolers. Applied Thermal Engineering, vol. 127, p. 1233-1245, D0l:10.1016/j. applthermaleng.2017.08.136.

[67] Chavan, D., Pise, A.T. (2014). Performance investigation of an automotive car radiator operated with nanofluid as a coolant. Journal of Thermal Science and Engineering Applications, vol. 6, no. 2, ID 021010, D0I:10.1115/1.4025230.

[68] Asadi, A., Asadi, M., Rezaniakolaei, A., Rosendahl, L.A., Wongwises, S. (2018). An experimental and theoretical investigation on heat transfer capability of $\mathrm{Mg}(\mathrm{OH})_{2}$ /MWCNTengine oil hybrid nano-lubricant adopted as a coolant and lubricant fluid. Applied Thermal Engineering, vol. 129, p. 577 586, D0I:10.1016/j.applthermaleng.2017.10.074.

[69] Sözen, A., Variyenli, H.I.., Özdemir, M.B., Gürü, M., Aytaç, ì. (2016). Heat transfer enhancement using alumina and fly ash nanofluids in parallel and cross-flow concentric tube heat exchangers. Journal of the Energy Institute, vol. 89, no. 3, p. 414-424, D0I:10.1016/j.joei.2015.02.012.

[70] Madhesh, D., Kalaiselvam, S. (2014) Experimental analysis of hybrid nanofluid as a coolant. Procedia Engineering, vol. 97, p. 1667-1675, D0I:10.1016/j.proeng.2014.12.317.

[71] Ramachandran, R.N., Ganesan, K., Asirvatham, L.G. (2016). The role of hybrid nanofluids in improving the thermal characteristics of screen mesh cylindrical heat pipes. Thermal Science, vol. 20, no. 6, p. 2027-2035, Dol:10.2298/ TSCI150710006R.

[72] Shah, T.R., Ali, H.M. (2019). Applications of hybrid nanofluids in solar energy, practical limitations and challenges: A critical review. Solar Energy, vol. 183, p. 173-203, D0l:10.1016/j. solener.2019.03.012.

[73] Hader, M., Al-Kouz, W. (2018). Performance of a hybrid photovoltaic/thermal system utilizing water- $\mathrm{Al}_{2} \mathrm{O}_{3}$ nanofluid and fins. International Journal of Energy Research, vol. 43, no. 1, p. 219-230, DOI:10.1002/er.4253.

[74] Jin, X., Lin, G., Zeiny, A., Jin, H., Bai, L., Wen, D. (2019). Solar photothermal conversion characteristics of hybrid nanofluids: An experimental and numerical study. Renewable Energy, vol. 141, p. 937-949, Dol:10.1016/j.renene.2019.04.016. 
[75] Sidik, N.A.C., Adamu, I.M., Jamil, M.M., Kefayati, G.H.R., Mamat, R., Najafi, G. (2016). Recent progress on hybrid nanofluids in heat transfer applications: A comprehensive review. International Communications in Heat and Mass Transfer, vol. 78, p. 68-79, D0l:10.1016/j.icheatmasstransfer.2016.08.019.

[76] Huminic, G., Huminic, A. (2018). Heat transfer capability of the hybrid nanofluids for heat transfer applications. Journal of Molecular Liquids, vol. 272, p. 857-870, D0I:10.1016/j. molliq.2018.10.095.

[77] Al-Kouz, W.G., Kiwan, S., Alkhalidi, A., Sari, M.E., Alshare, A. (2018). Numerical study of heat transfer enhancement for low-pressure flows in a square cavity with two fins attached to the hot wall using $\mathrm{AL}_{2} \mathrm{O}_{3}$-air nanofluid. Strojniški vestnik Journal of Mechanical Engineering, vol. 64, no. 1, p. 26-36, DOI:10.5545/sv-jme.2017.4989.
[78] Al-Kouz, W., Alshare, A., Kiwan, S., Al-Muhtady, A., Alkhalidi, A., Saadeh, H. (2018). Two-dimensional analysis of low-pressure flows in an inclined square cavity with two fins attached to the hot wall. International Journal of Thermal Sciences, vol. 126, p. 181-193, D0I:10.1016/j.ijthermalsci.2018.01.005.

[79] Al-Kouz, W., Al-Muhtady, A., Owhaib, W., Al-Dahidi, S., Hader, M., Abu-Alghanam, R. (2019). Entropy generation optimization for rarified nanofluid flows in a square cavity with two fins at the hot wall. Entropy, vol. 21, no. 2, 103, D0l:10.3390/ e21020103.

[80] Al-Kouz, W., Al-Waked, R., Sari, M.E., Owhaib, W., Atieh, A. (2018). Numerical study of heat transfer enhancement in the entrance region for low-pressure gaseous laminar pipe flows using $\mathrm{Al}_{2} \mathrm{O}_{3}$-air nanofluid. Advances in Mechanical Engineering, vol. 10, no. 7, p. 1-11, Dol:10.1177/1687814018784410. 